\title{
Effect of Sources and Methods of Zinc Application on Productivity, Nutrient Uptake and Zinc Use Efficiency of Basmati rice (Oryza sativa L.)
}

\author{
Rahul Kumar*, Mukesh Kumar, Shipra Yadav and Rajendra Kumar \\ Department of Agronomy, Sardar Vallabhbhai Patel University of Agriculture \& Technology, \\ Meerut (U.P.) India \\ *Corresponding author
}

Keywords

Zinc, Zinc use efficiency, Productivity, Sources of zinc, Basmati rice

Article Info

Accepted: 22 December 2019 Available Online: 20 January 2020

A B S T R A C T

A field experiment entitled "Effect of sources and methods of zinc application on growth, yield and zinc use efficiency in Basmati rice (Oryza sativa L.)" was conducted at Crop Research Centre of Sardar Vallabhbhai Patel University of Agriculture \& Technology, Meerut, during kharif season of 2017 with ten treatments viz. control $\left(\mathrm{T}_{1}\right)$, Seedling treatment with $1 \% \mathrm{ZnO}$ solution (5 min.) $\left(\mathrm{T}_{2}\right), 5 \mathrm{~kg} \mathrm{Zn} / \mathrm{ha}$ through $\mathrm{ZnSO}_{4}(21 \% \mathrm{Zn})$ as soil application $\left(\mathrm{T}_{3}\right), 0.5 \mathrm{~kg} \mathrm{Zn} / \mathrm{ha}$ through Chelated zinc (Zn EDTA) as soil application $\left(\mathrm{T}_{4}\right)$, $7.5 \mathrm{~kg} \mathrm{Zn} / \mathrm{ha}$ through $\mathrm{ZnSO}_{4}(21 \% \mathrm{Zn})$ as soil application $\left(\mathrm{T}_{5}\right), 1 \mathrm{~kg} \mathrm{Zn} / \mathrm{ha}$ through Chelated zinc ( $\mathrm{Zn}$ EDTA) as soil application $\left(\mathrm{T}_{6}\right)$, Foliar spray of $\mathrm{ZnSO}_{4}$ with lime $(0.1 \%$ $\mathrm{Zn}$ solution $\left(\mathrm{T}_{7}\right)$, Foliar spray of $\mathrm{ZnSO}_{4}$ with urea $\left(0.1 \% \mathrm{Zn}\right.$ solution $\left(\mathrm{T}_{8}\right)$, Foliar spray of $\mathrm{ZnSO}_{4}$ with lime $\left(0.15 \%\right.$ Zn solution $\left(\mathrm{T}_{9}\right)$ and Foliar spray of $\mathrm{ZnSO}_{4}$ with urea $(0.15 \% \mathrm{Zn}$ solution $\left(\mathrm{T}_{10}\right)$. Experiment was laid out in randomized block design (RBD) with three replications. Grain, straw and biological yield of rice crop was influenced by different sources and methods of zinc application and was recorded significantly highest with the application of $7.5 \mathrm{~kg} \mathrm{Zn} /$ ha through $\mathrm{ZnSO}_{4}(21 \% \mathrm{Zn})$ as soil application $\left(\mathrm{T}_{5}\right)$. Highest zinc use efficiency was associated with the same treatment, similarly, this treatment also gave the maximum nutrient $(\mathrm{N}, \mathrm{K}$ and $\mathrm{Zn})$ content and uptake by grain and straw. The next in the order best treatments were $\mathrm{T}_{3}\left(5 \mathrm{~kg} \mathrm{Zn} / \mathrm{ha}\right.$ through $\mathrm{ZnSO}_{4}(21 \% \mathrm{Zn})$ as soil application) and $\mathrm{T}_{6}(1 \mathrm{~kg} \mathrm{Zn} /$ ha through Chelated zinc (Zn EDTA) as soil application).

\section{Introduction}

Rice (Oryza sativa L.) is the most important food crop in the world. Cultivation of rice is important to food security of Asia, where more than $90 \%$ of the global rice is produced and consumed. India is the second largest producer and consumer of rice in the world after china. In India, the area, production and productivity of rice is $43.79 \mathrm{mha}, 112.91 \mathrm{mt}$ and $2.57 \mathrm{t} / \mathrm{ha}$, respectively, (Anonymous,
2018). In India, it accounts more than $40 \%$ of food grain production, providing direct employment to $70 \%$ people in rural areas. Being the staple food for more than $65 \%$ of the people, our national food security hinges on the growth and stability of rice production. Rice provides protein, minerals, vitamins and fiber, although all constituents except carbohydrates are reduced during milling is realized as staple food by majority of world's population. 
Zinc deficiency is a serious problem for rice grown under wet land soil conditions in Uttar Pradesh. To alleviate such deficiency, $\mathrm{Zn}$ is applied to the soil in the form of $\mathrm{ZnSO}_{4}$ $.7 \mathrm{H}_{2} \mathrm{O}$. The recovery of applied $\mathrm{Zn}$ by rice is, however, very low, which may be due to its transformation to different chemical forms. Crop plants utilize only $1-4 \%$ of the freshly applied Zinc and the rest goes in to the formation of different $\mathrm{Zn}$ compound of varying solubility and availability of $\mathrm{Zn}$ to plants, generally, the regions in the world with $\mathrm{Zn}$ deficient soils are also characterized by widespread $\mathrm{Zn}$ deficiency in humans. Recent estimates indicate that nearly half of world population suffers from Zn deficiency (Cakmak, 2008). Cereal crops play an important role in satisfying daily calorie intake in developing world, but are inherently very low in $\mathrm{Zn}$ concentrations in grain, particularly when grown on $\mathrm{Zn}$ - deficient soils. The reliance on cereal- based diets may induce Zn-deficiency related problems in humans, such as impairments in physical developments, immune system and brain function.

Increasing incidences of $\mathrm{Zn}$ deficiency over the past several years have been due to various reasons. These include increased crop demand on soils ability to supply $\mathrm{Zn}$ fast enough as a result of improved cultivars and management, use of urea in place of acid fertilizer ammonium sulphate, increased use of phosphate fertilizers and the resulting $\mathrm{P}$ induced $\mathrm{Zn}$ deficiency; and the use of alkaline irrigation water without proper drainage. It is anticipated that further increase in incidences with the advent of rice with $\mathrm{Zn}$ dense grains for human nutrition which will have greater $\mathrm{Zn}$ requirement (Welch and Graham, 1999). Analysis of 25,000 plant samples collected from different states in India showed that $44 \%$ of the plant samples contained inadequate $\mathrm{Zn}$ (Singh, 2007). These values indicate that $\mathrm{Zn}$ deficiency in soils represents a particular constraint to crop yield and a major reason for the low dietary intake of $\mathrm{Zn}$.

The requirement of $\mathrm{Zn}$ for the function of a wide range of enzymes indicates that the metabolism of proteins, carbohydrates and auxin as well as reproductive processes are hampered under Zn deficiency (Romheld and Marschner, 1991). $\mathrm{Zn}$ is required for the activity of metallo enzymes that are involved in protein and nucleic acid metabolism. The different approaches for correction of zinc deficiency include dietary intervention, supplementation and biofortification through agronomic and genetic approaches for improving grain zinc concentration. Although, a large number of studies are available on the role of soil and foliar applied $\mathrm{Zn}$ fertilizers in correction of Zn deficiency and increasing plant growth and yield (Mortvedt and Gilkes 1993; Rengel et al., 1999). Zinc can be directly applied to soil as both organic and inorganic compounds. Zinc sulfate $\left(\mathrm{ZnSO}_{4}\right)$ is the most widely applied inorganic source of $\mathrm{Zn}$ due to its high solubility and low cost. Zinc can also be applied to soils in form of $\mathrm{ZnO}, \mathrm{Zn}$-EDTA and $\mathrm{Zn}$-oxysulfate.

\section{Materials and Methods}

A field experiment entitled "Effect of sources and methods of zinc application on growth, yield and zinc use efficiency in Basmati rice (Oryza sativa L.)" was conducted at Crop Research Centre of Sardar Vallabhbhai Patel University of Agriculture \& Technology, Meerut, during kharif season of 2017 with ten treatments viz control $\left(\mathrm{T}_{1}\right)$, Seedling treatment with $1 \% \mathrm{ZnO}$ solution (5 min.) $\left(\mathrm{T}_{2}\right)$, $5 \mathrm{~kg} \mathrm{Zn/ha} \mathrm{through} \mathrm{ZnSO}_{4}(21 \% \mathrm{Zn})$ as soil application $\left(\mathrm{T}_{3}\right), 0.5 \mathrm{~kg} \mathrm{Zn} / \mathrm{ha}$ through Chelated zinc (Zn EDTA) as soil application $\left(\mathrm{T}_{4}\right), 7.5 \mathrm{~kg} \mathrm{Zn} / \mathrm{ha}$ through $\mathrm{ZnSO}_{4}(21 \% \mathrm{Zn})$ as soil application $\left(\mathrm{T}_{5}\right), 1 \mathrm{~kg} \mathrm{Zn} / \mathrm{ha}$ through Chelated zinc (Zn EDTA) as soil application 
$\left(\mathrm{T}_{6}\right)$, Foliar spray of $\mathrm{ZnSO}_{4}$ with lime $(0.1 \%$ $\mathrm{Zn}$ solution $\left(\mathrm{T}_{7}\right)$, Foliar spray of $\mathrm{ZnSO}_{4}$ with urea $\left(0.1 \% \mathrm{Zn}\right.$ solution $\left(\mathrm{T}_{8}\right)$, Foliar spray of $\mathrm{ZnSO}_{4}$ with lime $\left(0.15 \% \mathrm{Zn}\right.$ solution $\left(\mathrm{T}_{9}\right)$ and Foliar spray of $\mathrm{ZnSO}_{4}$ with urea $(0.15 \% \mathrm{Zn}$ solution $\left(\mathrm{T}_{10}\right)$. Experiment was laidout in randomized block design (RBD) with three replications. The soil of the experimental field was sandy loam is texture and slightly alkaline in nature and low in organic carbon, available nitrogen, available potassium and medium in available phosphorus. The basmati rice (PB-1) was transplanted on $20^{\text {th }}$ July 2017.

\section{Results and Discussion}

\section{Biological Yield (q/ha)}

The maximum biological yield of $122.65 \mathrm{q}$ $\mathrm{ha}^{-1}$ was recorded with the application of 7.5 $\mathrm{kg} \mathrm{Zn} / \mathrm{ha}$ through $\mathrm{ZnSO}_{4}(21 \% \mathrm{Zn})$ as soil application $\left(\mathrm{T}_{5}\right)$ which was statistically at par with $\mathrm{T}_{3}\left(5 \mathrm{~kg} \mathrm{Zn/ha} \mathrm{through} \mathrm{ZnSO}_{4}(21 \% \mathrm{Zn})\right.$ as soil application) and $\mathrm{T}_{6}(1 \mathrm{~kg} \mathrm{Zn} / \mathrm{ha}$ through Chelated zinc (Zn EDTA) as soil application) with the straw yield of 120.80 and $119.90 \mathrm{q} \mathrm{ha}^{-1}$ respectively. The increment in biological yield under treatment $\mathrm{T}_{5}(7.5 \mathrm{~kg}$ $\mathrm{Zn} /$ ha through $\mathrm{ZnSO}_{4}(21 \% \quad \mathrm{Zn})$ as soil application) was to the tune of $20.48 \%$ over control $\left(\mathrm{T}_{1}\right)$. However, the lowest biological yield (97.52 $\mathrm{q} \mathrm{ha}^{-1}$ ) was recorded under control plots $\left(\mathrm{T}_{1}\right)$.

\section{Grain Yield (q/ha)}

Sources and methods of zinc application caused significant variation in grain yield $(\mathrm{q}$ $\mathrm{ha}^{-1}$ ) of rice. The maximum grain yield of $53.30 \mathrm{q} \mathrm{ha}^{-1}$ was recorded with the application of $7.5 \mathrm{~kg} \mathrm{Zn} /$ ha through $\mathrm{ZnSO}_{4}(21 \% \mathrm{Zn})$ as soil application $\left(\mathrm{T}_{5}\right)$ which was significantly at par with $\mathrm{T}_{3}\left(5 \mathrm{~kg} \mathrm{Zn} / \mathrm{ha}\right.$ through $\mathrm{ZnSO}_{4}$ $(21 \% \mathrm{Zn})$ as soil application) and $\mathrm{T}_{6}(1 \mathrm{~kg}$ $\mathrm{Zn} /$ ha through Chelated zinc (Zn EDTA) as soil application) with the yield of 52.50 and $51.90 \mathrm{q} \mathrm{ha}^{-1}$, respectively. The increment in grain yield under treatment $\mathrm{T}_{5}(7.5 \mathrm{~kg} \mathrm{Zn} / \mathrm{ha}$ through $\mathrm{ZnSO}_{4}(21 \% \mathrm{Zn})$ as soil application) was to the tune of $23.32 \%$ over $\mathrm{T}_{1}$ (control). However, the lowest grain yield (40.87 $\left.\mathrm{q} \mathrm{ha}^{-1}\right)$ was recorded under control plot $\left(\mathrm{T}_{1}\right)$.

Crop productivity is the rate at which a crop accumulate biomass which depends primarily on the photosynthesis and conversion of light energy into chemical energy by green plants. The yield of rice (Table 4.6) is composed of yield components like as number of panicles, panicle length and 1000 grain weight. Though, 1000 grain weight an influence on grain yield but its effect is lower than panicle length and number of grains panicle ${ }^{-1}$. All sources and methods of zinc application differ significantly from each other except $\mathrm{T}_{5}$ and $\mathrm{T}_{3}$ and $\mathrm{T}_{6}$. Positive effects of micronutrients application by soil and foliar sprays on grain yield of rice might be due to increase chlorophyll content of leaves of rice which might have increased photosynthesis and resulted in more dry matter accumulation and leaf area and hence lead to more capture of solar radiation that resulted in enhanced values of growth parameters and yield contributing characters and ultimately resulted in higher grain yield. These results are in line with Slaton et al., (2005), Khattak et al., (2015) and Ghoneim (2016).

\section{Straw Yield (q/ha)}

The straw yield differs from 56.65 to $69.35 \mathrm{q}$ $\mathrm{ha}^{-1}$. The maximum straw yield $\left(69.35 \mathrm{q} \mathrm{ha}^{-1}\right)$ was recorded with the application of $7.5 \mathrm{~kg}$ $\mathrm{Zn} /$ ha through $\mathrm{ZnSO}_{4}\left(\begin{array}{lll}21 \% & \mathrm{Zn}\end{array}\right)$ as soil application (T5) which was statistically at par with all the treatments except $\mathrm{T}_{1}$ (control) and $\mathrm{T}_{2}$ (Seedling treatment with $1 \% \mathrm{ZnO}$ solution (5 min.). The increment in straw yield under treatment $\mathrm{T}_{5}\left(7.5 \mathrm{~kg} \mathrm{Zn} / \mathrm{ha}\right.$ through $\mathrm{ZnSO}_{4}$ $(21 \% \mathrm{Zn})$ as soil application) was to the tune 
of $18.38 \%$ over $\mathrm{T}_{1}$ (control). However, significantly lowest straw yield $\left(56.65 \mathrm{q} \mathrm{ha}^{-1}\right)$ was recorded in control treatment $\left(T_{1}\right)$. The straw yield is function of crop biomass developed during the crop growth period and also makes important contribution to the overall crop residues as it is used as feed for the cattle. The straw yield is depicted in all the treatments were significantly higher than control. Among the various zinc sources and methods of zinc application $\mathrm{T}_{5}(7.5 \mathrm{~kg} \mathrm{Zn} / \mathrm{ha}$ through $\mathrm{ZnSO}_{4}(21 \% \mathrm{Zn})$ as soil application) gave significantly higher straw yield during the year of study. Higher straw yield with higher levels of zinc could be due to more number of tillers $\mathrm{sq} \mathrm{m}^{-1}$, dry matter accumulation and plant height as compared to other treatments

\section{Harvest Index (\%)}

Harvest index which is a ratio of grain yield to biological yield was highest $(43.50 \%)$ with the application of $7.5 \mathrm{~kg} \mathrm{Zn/ha}$ through $\mathrm{ZnSO}_{4}(21 \% \mathrm{Zn})$ as soil application $\left(\mathrm{T}_{5}\right)$ followed by $\mathrm{T}_{3}\left(5 \mathrm{~kg} \mathrm{Zn} / \mathrm{ha}\right.$ through $\mathrm{ZnSO}_{4}$ $(21 \% \mathrm{Zn})$ as soil application) and $\mathrm{T}_{6}(1 \mathrm{~kg}$ $\mathrm{Zn} / \mathrm{ha}$ through Chelated zinc (Zn EDTA) as soil application) which gave 43.46 and 43.29 percent harvest index, respectively. The lowest harvest index (41.91\%) was observed in control treatment $\left(\mathrm{T}_{1}\right)$.

Total dry matter accumulation (Grain + straw) by crop is an important index indicating the photosynthetic efficiency of crop and photosynthesis left behind after respiration which ultimately influences the crop yield. The data as presented in revealed that highest biological yield was obtained in the treatments of nutrient management (Table 4.6). All the treatments proved significantly higher than control. Significantly higher biological yield with $\mathrm{T}_{5}$ as compared to all other zinc treatment during the year of study. The $T_{5}$ treatment proved significantly more biological yield over control and $\mathrm{T}_{3}$ and $\mathrm{T}_{6}$ treatments also recorded significantly more biological yield over control treatment. The supply of micronutrients such as $\mathrm{Zn}$ through foliar application resulted in better absorption of these nutrients, thereby helping in the photosynthetic activities and effective translocation to storage organs. Singh et al., (2014) study was observed the highest Basmati rice grain, straw and biological yield showed positive correlation with the increase in $\mathrm{ZnSO}_{4}$ level from 2.5 to $10 \mathrm{~kg} \mathrm{ha}^{-1}$ similar result were observed Cheema et al., (2006) and Shivay et al., (2010).

\section{Nutrient uptake}

\section{Nitrogen uptake}

The total nitrogen uptake (grains+straw) was significantly increased by different treatments over control. The highest total $\mathrm{N}$ uptake 93.93 $\mathrm{kg} \mathrm{ha}^{-1}$ was recorded with the application of $7.5 \mathrm{~kg} \mathrm{Zn} / \mathrm{ha}$ through $\mathrm{ZnSO}_{4}(21 \% \mathrm{Zn})$ as soil application $\left(\mathrm{T}_{5}\right)$ which was statistically at par with $\mathrm{T}_{3}$ (89.94) and $\mathrm{T}_{6}\left(85.08 \mathrm{~kg} \mathrm{ha}^{-1}\right)$. However, the minimum nitrogen uptake by rice grains (41.06), straw (19.59) and total $\left(60.65 \mathrm{~kg} \mathrm{ha}^{-1}\right)$ was recorded under control treatment $\left(\mathrm{T}_{1}\right)$.

\section{Phosphorus uptake}

The phosphorus uptake by grains was not significantly influenced by sources and methods of zinc application however, the maximum uptake was noticed with foliar spray of $\mathrm{ZnSO}_{4}$ with urea $(0.15 \% \quad \mathrm{Zn}$ solution). Phosphorus uptake in rice straw ranged from 6.06 to $9.28 \mathrm{~kg} \mathrm{ha}^{-1}$ and the highest phosphorus uptake $\left(9.28 \mathrm{~kg} \mathrm{ha}^{-1}\right)$ was recorded with the application of $7.5 \mathrm{~kg} \mathrm{Zn} / \mathrm{ha}$ through $\mathrm{ZnSO}_{4}(21 \% \mathrm{Zn})$ as soil application $\left(\mathrm{T}_{5}\right)$ which was statistically at par with all the treatments except $\mathrm{T}_{1}$ (control) and $\mathrm{T}_{2}$ (Seedling treatment with $1 \% \mathrm{ZnO}$ solution (5 
min.). Total P-uptake ranged from 16.19 to $23.68 \mathrm{~kg} \mathrm{ha}^{-1}$. Highest total P uptake $(23.68$ $\mathrm{kg} \mathrm{ha}^{-1}$ ) was recorded in $\mathrm{T}_{10}$ (Foliar spray of $\mathrm{ZnSO}_{4}$ with urea $(0.15 \% \mathrm{Zn}$ solution $)$ which was statistically at par with all the treatments except control $\left(\mathrm{T}_{1}\right)$. However, the minimum phosphorus uptake by rice grains (10.13), straw (6.06) and total (16.19 $\left.\mathrm{kg} \mathrm{ha}^{-1}\right)$ was recorded under control treatment $\left(\mathrm{T}_{1}\right)$.

\section{Potassium uptake}

The maximum potassium uptake of $21.43 \mathrm{~kg}$ $\mathrm{ha}^{-1}$ in rice grains was recorded in $\mathrm{T}_{5}(7.5 \mathrm{~kg}$ $\mathrm{Zn} /$ ha through $\mathrm{ZnSO}_{4}\left(\begin{array}{lll}21 \% & \mathrm{Zn}\end{array}\right)$ as soil application) which was statistically at par with $\mathrm{T}_{3}(20.55)$ and $\mathrm{T}_{6}\left(19.78 \mathrm{~kg} \mathrm{ha}^{-1}\right)$. In rice straw maximum potassium uptake $(103.83 \mathrm{~kg}$ $\left.\mathrm{ha}^{-1}\right)$ was recorded in $\mathrm{T}_{5}(7.5 \mathrm{~kg} \mathrm{Zn} / \mathrm{ha}$ through $\mathrm{ZnSO}_{4}(21 \% \mathrm{Zn})$ as soil application $)$ which was statistically at par with $\mathrm{T}_{3}$ (100.49), $\mathrm{T}_{6}$ (100.35), $\mathrm{T}_{4}$ (93.81), $\mathrm{T}_{10}$ (92.97) and $\mathrm{T}_{9}\left(92.53 \mathrm{~kg} \mathrm{ha}{ }^{-1}\right)$. Total potassium uptake by rice (grains+straw) was recorded highest in $\mathrm{T}_{5}\left(7.5 \mathrm{~kg} \mathrm{Zn} /\right.$ ha through $\mathrm{ZnSO}_{4}$ $(21 \% \mathrm{Zn})$ as soil application) which was statistically at par with $\mathrm{T}_{3}$ (121.04) and $\mathrm{T}_{6}$ $\left(120.12 \mathrm{~kg} \mathrm{ha}^{-1}\right)$. However, the minimum potassium uptake by rice grains (13.54), straw (79.52) and total $\left(93.06 \mathrm{~kg} \mathrm{ha}^{-1}\right)$ was recorded under control $\left(\mathrm{T}_{1}\right)$.

\section{Zinc uptake}

The zinc uptake by rice grains, straw and total ranged from 198.20 to $299.21,79.32$ to 177.52 and 277.52 to $476.72 \mathrm{~g} \mathrm{ha}^{-1}$, respectively. The highest zinc uptake by rice grains (299.21 $\mathrm{g} \mathrm{ha}^{-1}$ ) was recorded in with the application of $7.5 \mathrm{~kg} \mathrm{Zn} / \mathrm{ha}$ through $\mathrm{ZnSO}_{4}(21 \% \quad \mathrm{Zn})$ as soil application $\left(\mathrm{T}_{5}\right)$ which was statistically at par with $\mathrm{T}_{6}(285.41)$ and $\mathrm{T}_{3}\left(283.94 \mathrm{~g} \mathrm{ha}^{-1}\right)$. While, the maximum zinc uptake by rice straw (177.52 $\mathrm{g} \mathrm{ha}^{-1}$ ) was recorded in case of T5 $(7.5 \mathrm{~kg} \mathrm{Zn/ha} \mathrm{through}$ $\mathrm{ZnSO}_{4}(21 \% \mathrm{Zn})$ as soil application) which was statistically at par with T3 (170.30), T6
(167.78), $\mathrm{T}_{10}$ (147.31) and $\mathrm{T}_{9}\left(146.54 \mathrm{~g} \mathrm{ha}^{-1}\right)$. However, the minimum zinc uptake by grains (198.20 $\mathrm{g} \mathrm{ha}^{-1}$ ), straw (79.31 $\mathrm{g} \mathrm{ha}^{-1}$ ) and total (277.52 $\mathrm{g} \mathrm{ha}^{-1}$ ) was recorded under control $\left(\mathrm{T}_{1}\right)$.

Nitrogen, phosphorus, potassium and zinc content in grain and straw (Table 2) were highest with the application of $7.5 \mathrm{~kg} \mathrm{Zn}$ through $\mathrm{ZnSO}_{4}(21 \% \mathrm{Zn})$ as soil application $\left(\mathrm{T}_{5}\right)$ over all other treatments. However, phosphorus content and uptake was in treatment $\mathrm{T}_{10}$ (foliar spray of $\mathrm{ZnSO}_{4}$ with urea $(0.15 \% \mathrm{Zn}$ solution). It was also mainly due to lack of application of zinc and its deficiency in Western Uttar Pradesh (Adhikari and Rattan, (2007). Sources of zinc application i.e. $7.5 \mathrm{~kg} \mathrm{Zn}$ through $\mathrm{ZnSO}_{4}$ $(21 \% \mathrm{Zn})$ as soil application and method of zinc application i.e. foliar application of $\mathrm{ZnSO}_{4}$ with urea $(0.15 \% \mathrm{Zn}$ solution) had recorded maximum nutrient concentration over rest of the treatments due to adequate zinc supply during reproductive growth phase was probably responsible in enhancing nutrient concentration. Further, treatments T3 and T9 had recorded higher nitrogen, phosphorus, potassium and zinc content in grain and straw over sources of zinc application and methods. Similar results was reported by Beebout et al., (2010) and Gao. et al., (2012). Application of zinc sources and methods readily increases the availability of nutrient concerned in the soil solution thereby enhancing its absorption by the plant roots and further translocation to the site of action. The beneficial effect of $\mathrm{Zn}$ when applied in conjunction with NPK might have helped in increasing and balancing the availability of essential plant nutrients and organic fertilizers sustained it over a long time. The concentration of nutrient also increase due to NPK and $\mathrm{Zn}$ fertilizer because of improved nutritional environment in rhizosphere and consequently in plant system (Ghatak et al., 2005 and Kumar et al., 2017). 


\section{Zinc use efficiency}

\section{Partial Factor Productivity (PFP)}

The application of $0.5 \mathrm{~kg} \mathrm{Zn} / \mathrm{ha}$ through Chelated zinc (Zn EDTA) as soil application $\left(\mathrm{T}_{4}\right)$ brought significantly maximum partial factor productivity $(9307.33 \mathrm{~kg}$ grain yield $/ \mathrm{kg}$ of zinc applied) followed by $\mathrm{T}_{8}$ (8071.34) and $\mathrm{T}_{7} \quad(7959.86 \mathrm{~kg}$ grain yield $/ \mathrm{kg}$ of zinc applied). However, the lowest partial factor productivity of $710.66 \mathrm{~kg}$ grain yield $/ \mathrm{kg}$ of zinc applied was noticed in $T_{5}(7.5 \mathrm{~kg} \mathrm{Zn} / \mathrm{ha}$ through $\mathrm{ZnSO}_{4}(21 \% \mathrm{Zn})$ as soil application) treatment followed by $\mathrm{T}_{3}(1432.67 \mathrm{~kg}$ grain yield $/ \mathrm{kg}$ of zinc applied). The minimum value of PFP was noticed in control treatment.

\section{Agronomic Efficiency (AE)}

The agronomic efficiency was significantly influenced by sources and methods of zinc application. The maximum agronomic efficiency was noticed with foliar spray of $\mathrm{ZnSO}_{4}$ with urea $(0.1 \% \mathrm{Zn}$ solution $)$ in $\mathrm{T}_{8}$ treatment which remained statistically par with $\mathrm{T}_{7}$ (Foliar spray of $\mathrm{ZnSO}_{4}$ with lime $\left(0.1 \% \mathrm{Zn}\right.$ solution), $\mathrm{T}_{4}(0.5 \mathrm{~kg} \mathrm{Zn} / \mathrm{ha}$ through Chelated zinc (Zn EDTA) as soil application), $\mathrm{T}_{6}(1 \mathrm{~kg} \mathrm{Zn/ha}$ through Chelated zinc (Zn EDTA) as soil application), $\mathrm{T}_{10}$ (Foliar spray of $\mathrm{ZnSO}_{4}$ with urea $(0.15 \% \mathrm{Zn}$ solution) and $\mathrm{T}_{9}$ (Foliar spray of $\mathrm{ZnSO}_{4}$ with lime $(0.15 \%$ Zn solution) Treatments.

Table.1 Grain, straw, biomass yield ( $\left(\mathrm{q}^{-1}\right)$ and harvest index as influenced by sources and methods of zinc application

\begin{tabular}{|c|c|c|c|c|}
\hline Treatments & $\begin{array}{c}\text { Biomass } \\
\text { yield }\end{array}$ & Grain yield & Straw yield & Harvest index \\
\hline$\left(T_{1}\right)$ Control & 97.52 & 40.87 & 56.65 & 41.91 \\
\hline $\begin{array}{l}\left(\mathrm{T}_{2}\right) \text { Seedling treatment with } 1 \% \mathrm{ZnO} \\
\text { solution }(5 \text { min.). }\end{array}$ & 106.79 & 44.87 & 61.92 & 42.04 \\
\hline $\begin{array}{l}\left(\mathrm{T}_{3}\right) 5 \mathrm{~kg} \mathrm{Zn} / \text { ha through } \mathrm{ZnSO}_{4}(21 \% \mathrm{Zn}) \text { as } \\
\text { soil application. }\end{array}$ & 120.80 & 52.50 & 68.30 & 43.46 \\
\hline $\begin{array}{l}\left(\mathrm{T}_{4}\right) 0.5 \mathrm{~kg} \mathrm{Zn} / \mathrm{ha} \text { through Chelated zinc }(\mathrm{Zn} \\
\text { EDTA) as soil application. }\end{array}$ & 111.22 & 46.54 & 64.68 & 41.84 \\
\hline $\begin{array}{l}\left(\mathrm{T}_{5}\right) 7.5 \mathrm{~kg} \mathrm{Zn} / \mathrm{ha} \text { through } \mathrm{ZnSO}_{4}(21 \% \mathrm{Zn}) \text { as } \\
\text { soil application. }\end{array}$ & 122.65 & 53.30 & 69.35 & 43.50 \\
\hline $\begin{array}{l}\left(\mathrm{T}_{6}\right) 1 \mathrm{~kg} \mathrm{Zn} / \mathrm{ha} \text { through Chelated zinc }(\mathrm{Zn} \\
\text { EDTA) as soil application. }\end{array}$ & 119.90 & 51.90 & 68.00 & 43.29 \\
\hline $\begin{array}{l}\left(\mathrm{T}_{7}\right) \text { Foliar spray of } \mathrm{ZnSO}_{4} \text { with lime }(0.1 \% \\
\text { Zn solution). }\end{array}$ & 110.61 & 47.60 & 63.01 & 43.06 \\
\hline $\begin{array}{l}\left(\mathrm{T}_{8}\right) \text { Foliar spray of } \mathrm{ZnSO}_{4} \text { with urea }(0.1 \% \\
\text { Zn solution). }\end{array}$ & 111.29 & 48.27 & 63.02 & 43.37 \\
\hline $\begin{array}{l}\left.\text { ( } \mathrm{T}_{9}\right) \text { Foliar spray of } \mathrm{ZnSO}_{4} \text { with lime }(0.15 \% \\
\mathrm{Zn} \text { solution). }\end{array}$ & 112.75 & 48.67 & 64.09 & 43.18 \\
\hline $\begin{array}{l}\left(\mathrm{T}_{10}\right) \text { Foliar spray of } \mathrm{ZnSO}_{4} \text { with urea }(0.15 \% \\
\mathrm{Zn} \text { solution). }\end{array}$ & 113.31 & 49.17 & 64.14 & 43.41 \\
\hline SEm \pm & 2.68 & 0.90 & 2.31 & - \\
\hline $\mathrm{CD}(P=0.05)$ & 8.04 & 2.69 & 6.93 & - \\
\hline
\end{tabular}


Fig.1 Mean weekly agro-meteorological data during the crop growing season (kharif-2017)

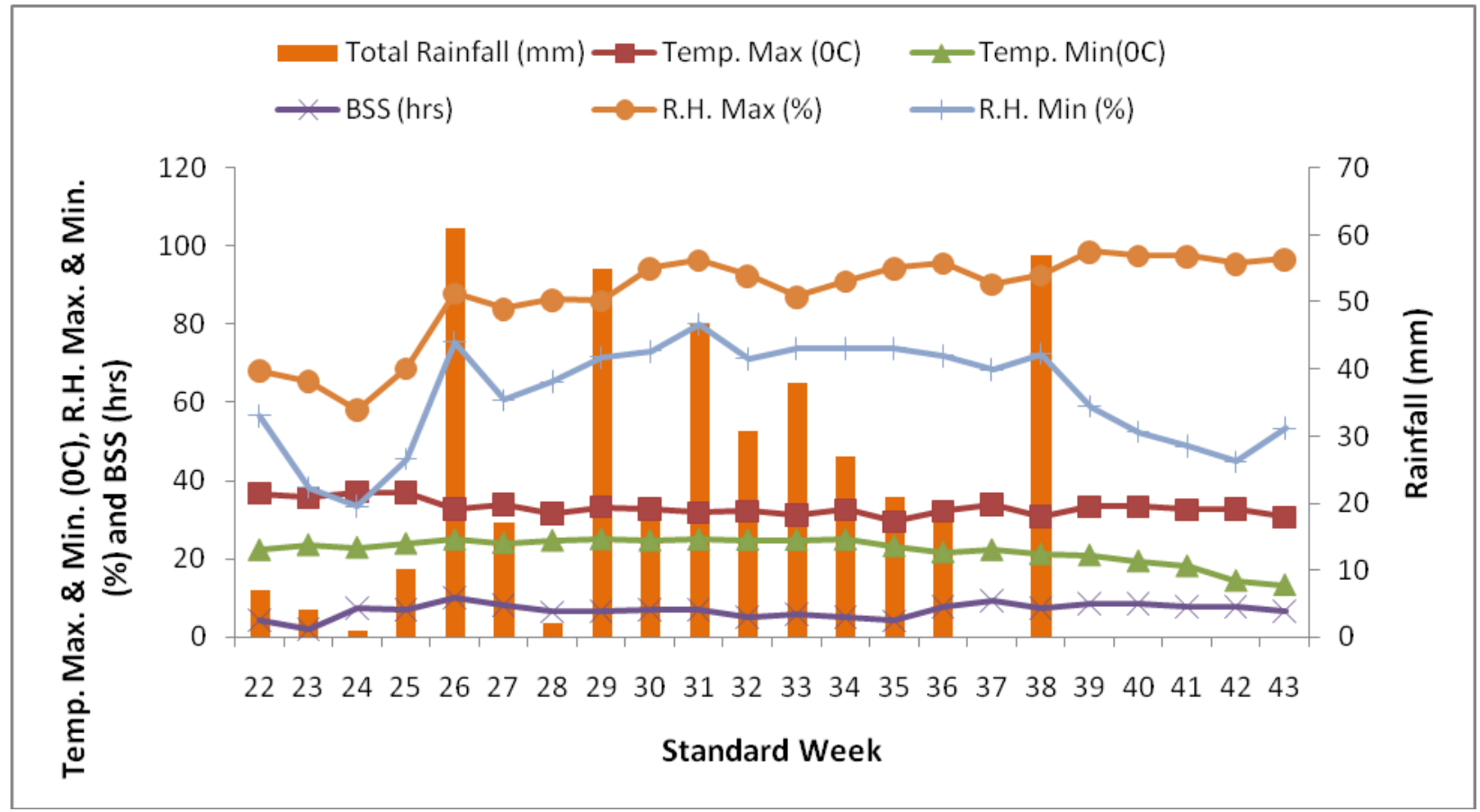

Fig.2 Grain, straw, biomass yield ( $\left(\mathrm{ha}^{-1}\right)$ and harvest index as influenced by sources and methods of zinc application

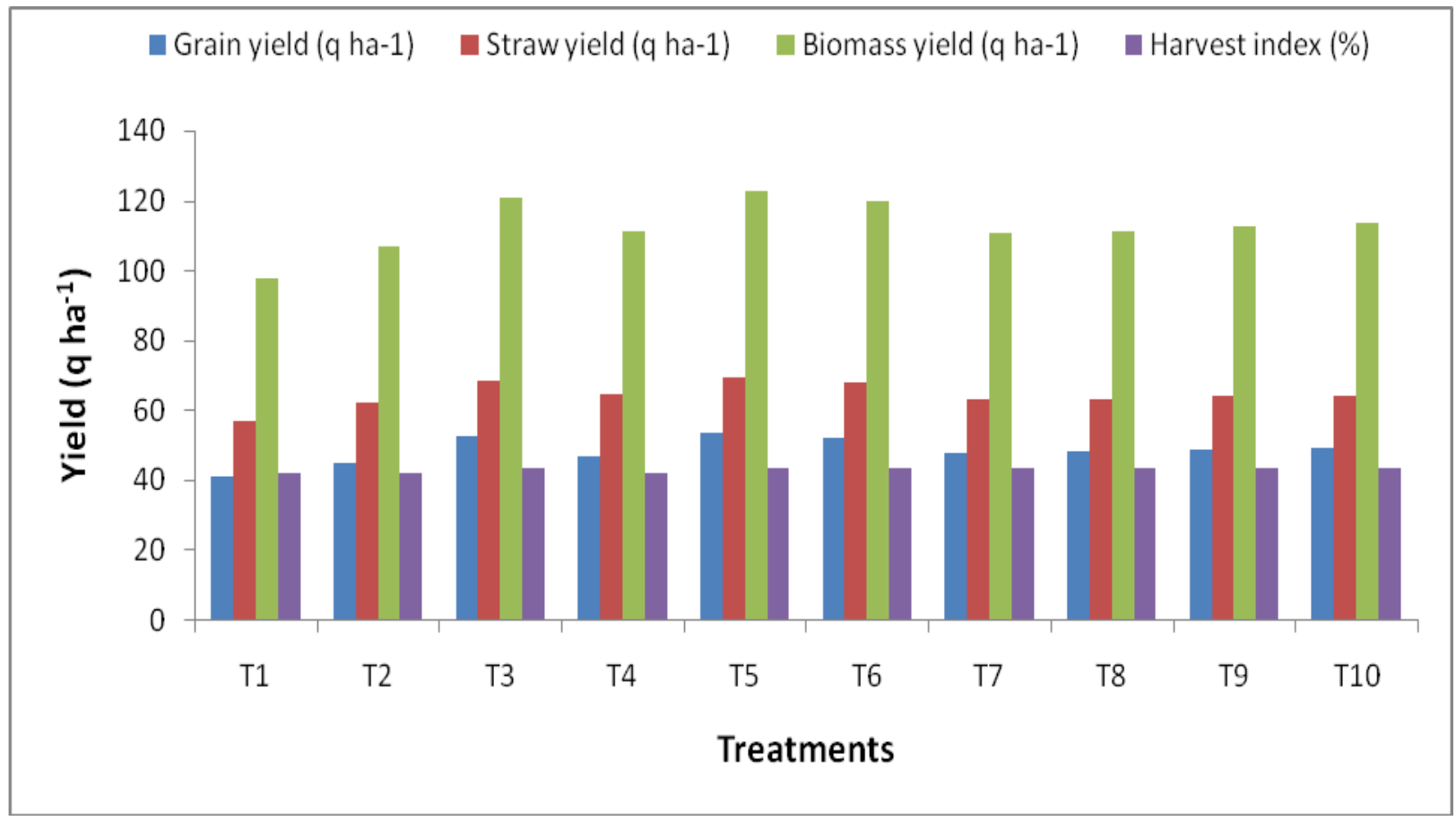


Fig.3 Nitrogen content and uptake by grain and straw of rice crop as influenced by sources and methods of zinc application

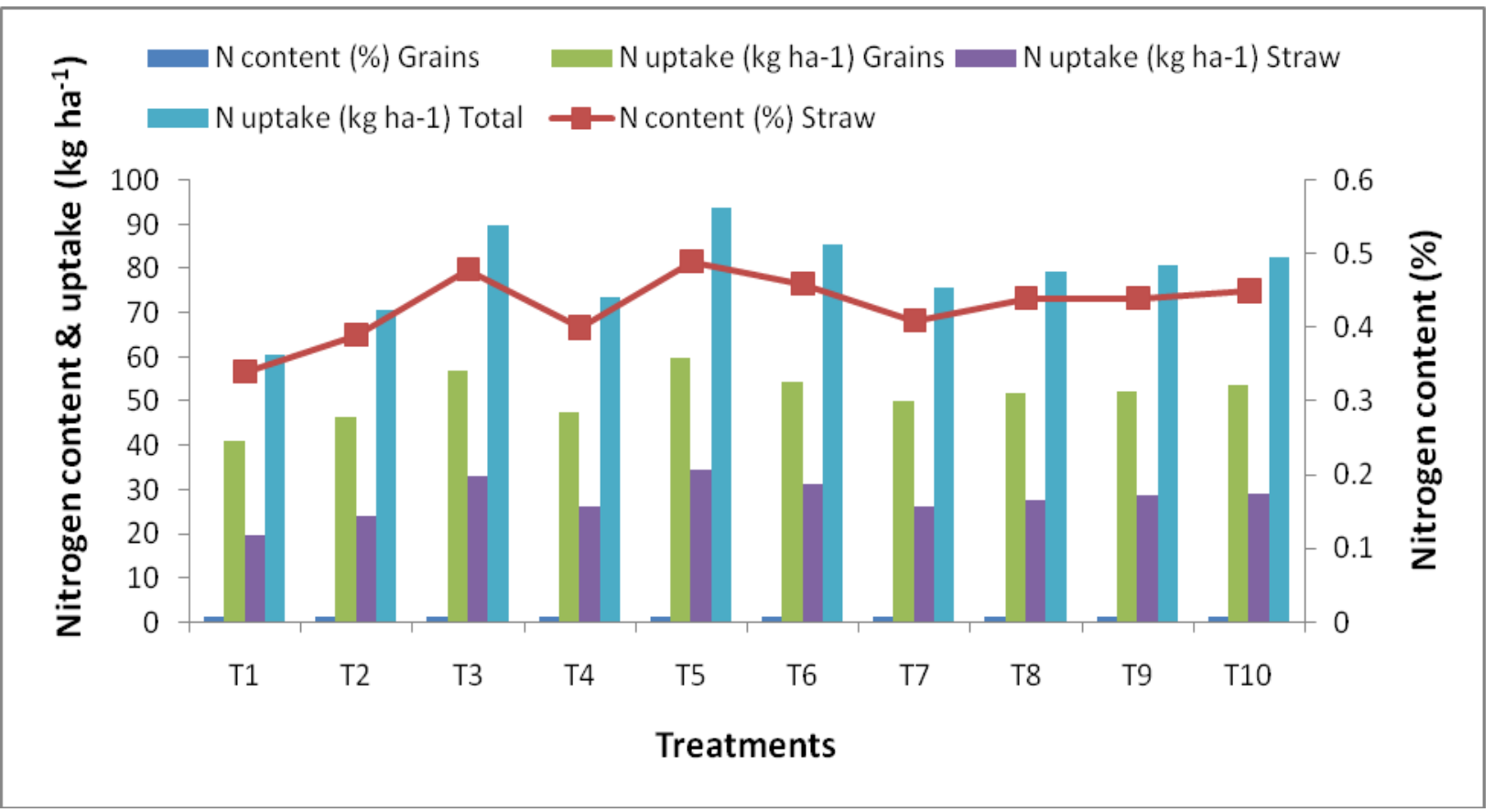

Fig.4 Phosphorus content and uptake by grain and straw of rice crop as influenced by sources and methods of zinc application

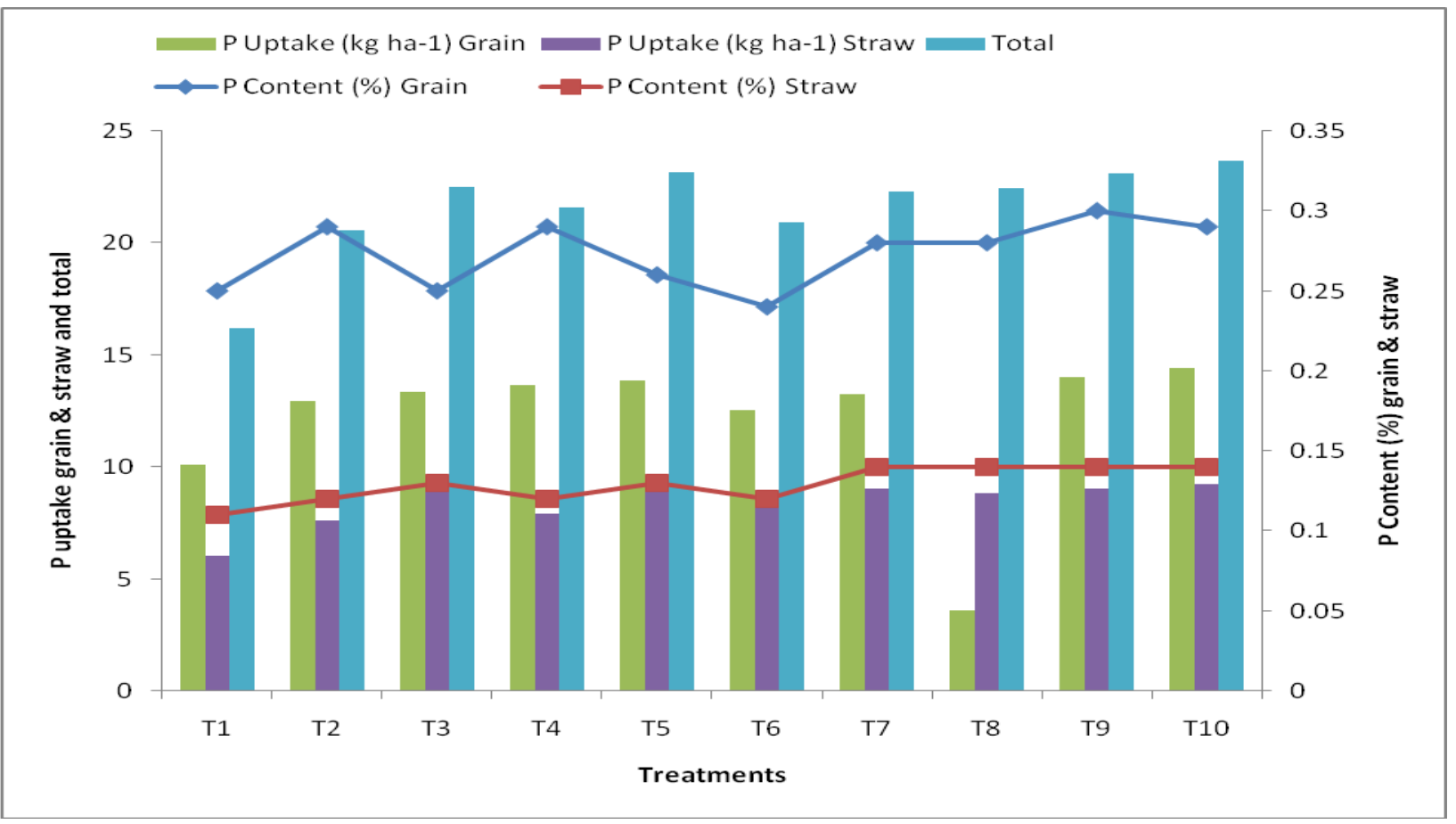


Fig.5 Potassium content and uptake by grain and straw of rice crop as influenced by sources and methods of zinc application

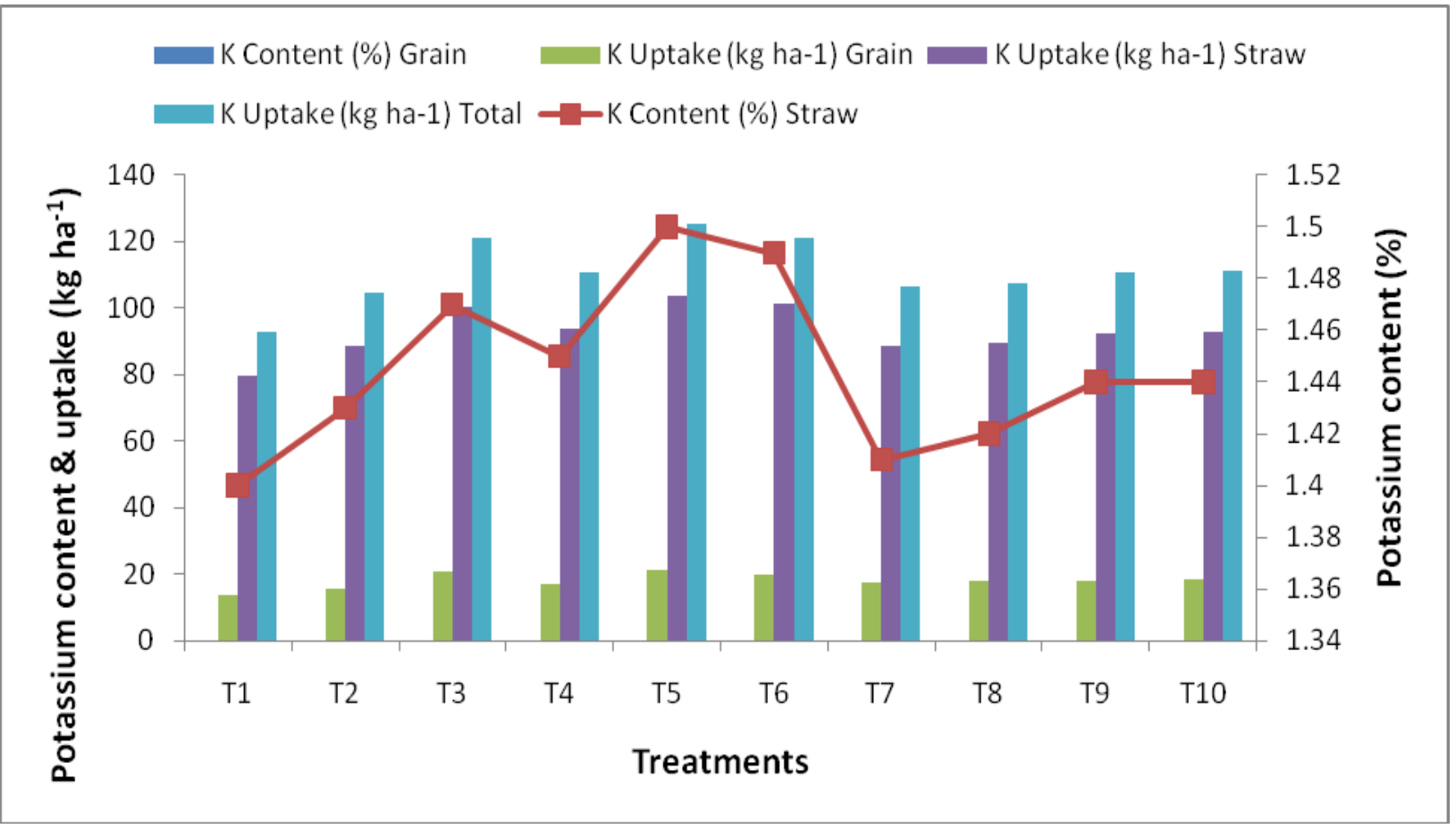

Fig.6 Zinc content and uptake by grain and straw of rice crop as influenced by sources and methods of zinc application

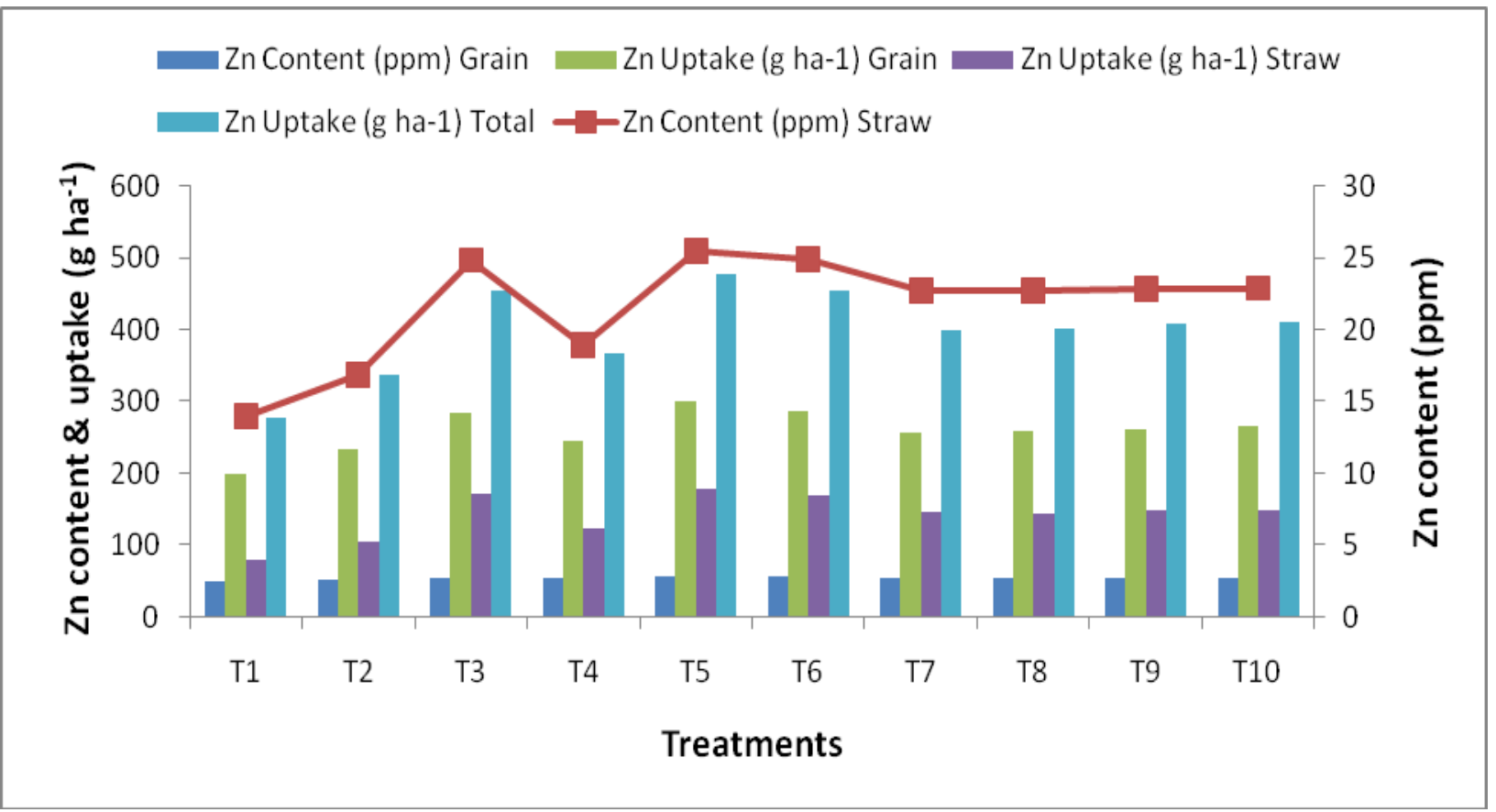


Fig.7 Zinc use efficiency viz. PEP, AE, NRE and PE as influenced by sources and methods of zinc application

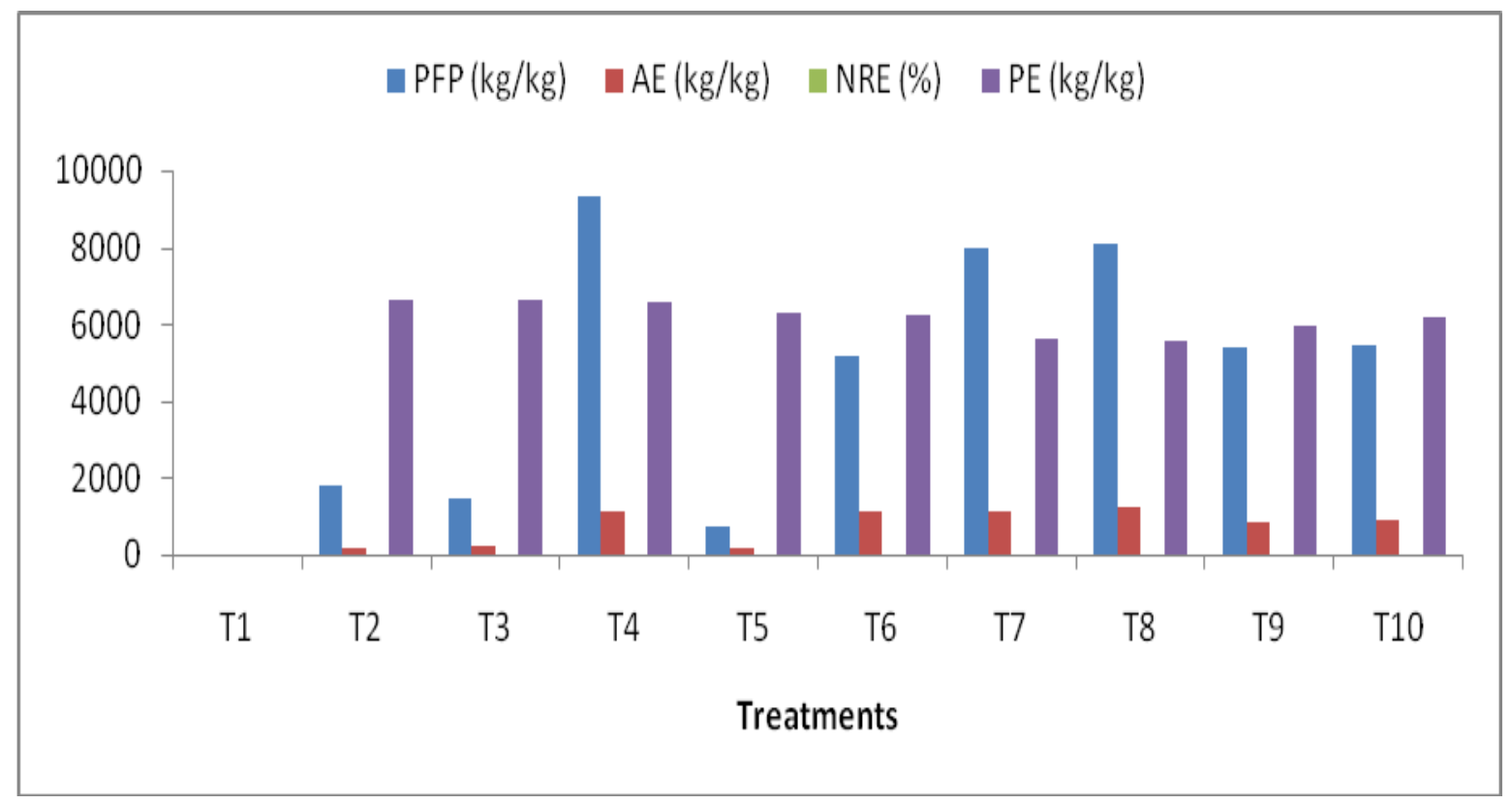

The application of Foliar spray of $\mathrm{ZnSO}_{4}$ with urea $(0.1 \% \quad \mathrm{Zn}$ solution) improved the agronomic efficiency by $86.60 \%$ over $7.5 \mathrm{~kg}$ $\mathrm{Zn} /$ ha through $\mathrm{ZnSO}_{4}\left(\begin{array}{lll}21 \% & \mathrm{Zn}\end{array}\right)$ as soil application $\left(\mathrm{T}_{5}\right)$. While, the lowest agronomic efficiency (160 kg grain yield increase per $\mathrm{kg}$ of zinc applied) was recorded with the application of seedling treatment with $1 \%$ $\mathrm{ZnO}$ solution $\left(\mathrm{T}_{2}\right)$.

\section{Recovery efficiency (RE)}

The recovery efficiency in rice crop varied from $2.39 \%$ to $22.46 \%$ among various treatments. The highest value of recovery efficiency $(22.46 \%)$ were found with the application of foliar spray of $\mathrm{ZnSO}_{4}$ with urea $(0.1 \% \mathrm{Zn}$ solution) which was statistically at par with $\mathrm{T}_{7}$ (foliar spray of $\mathrm{ZnSO}_{4}$ with lime ( $0.1 \% \mathrm{Zn}$ solution), $\mathrm{T}_{6}(1 \mathrm{~kg} \mathrm{Zn} / \mathrm{ha}$ through Chelated zinc (Zn EDTA) as soil application), $\mathrm{T}_{4}(0.5 \mathrm{~kg} \mathrm{Zn} / \mathrm{ha}$ through Chelated zinc ( $\mathrm{Zn}$ EDTA) as soil application), $\mathrm{T}_{9}$ (Foliar spray of $\mathrm{ZnSO}_{4}$ with lime $(0.15 \% \mathrm{Zn}$ solution) and $\mathrm{T}_{10}$ (Foliar spray of $\mathrm{ZnSO}_{4}$ with urea $(0.15 \%$ $\mathrm{Zn}$ solution). However, the per cent increment in $\mathrm{T}_{8}$ over $\mathrm{T}_{2}$ and $\mathrm{T}_{5}$ was 89.35 and $88.20 \%$, respectively. While, lowest crop recovery efficiency $(2.39 \%)$ was recorded with application of seedling treatment with $1 \%$ $\mathrm{ZnO}$ solution $\left(\mathrm{T}_{2}\right)$.

\section{Physiological efficiency (PE)}

The physiological efficiency (PE) varied from 5561.91 to $6654.32 \mathrm{~kg}$ grain yield per $\mathrm{kg}$ of zinc uptake among different treatments, being maximum in $\mathrm{T}_{3}\left(5 \mathrm{~kg} \mathrm{Zn} / \mathrm{ha}\right.$ through $\mathrm{ZnSO}_{4}$ $(21 \% \mathrm{Zn})$ as soil application). The application of $5 \mathrm{~kg} \mathrm{Zn} / \mathrm{ha}$ through $\mathrm{ZnSO}_{4}(21 \% \mathrm{Zn})$ as soil application $\left(\mathrm{T}_{3}\right)$ increased the $\mathrm{PE}$ by $16.41 \%$ as compared to $\left(\mathrm{T}_{8}\right)$ which showed the lowest physiological efficiency.

From the forgoing discussion it has been cleared and concluded that the application of $7.5 \mathrm{~kg} \mathrm{Zn} /$ ha through $\mathrm{ZnSO}_{4}(21 \% \mathrm{Zn})$ as soil application resulted into maximum growth and yield attributes viz. Plant height, number of tillers $/ \mathrm{m}^{2}$, dry matter accumulation, number of panicles $/ \mathrm{m}^{2}$, panicle length, grains/panicle and test weight and grain, straw and 
biological yield of rice crop. Similarly, this treatment also gave the maximum nutrient $(\mathrm{N}$, $\mathrm{P}, \mathrm{K}$ and $\mathrm{Zn}$ ) content and uptake. However, the highest partial factor productivity (PFP) of zinc was associated with the application of $0.5 \mathrm{~kg}$ chelated zinc/ha to the soil whereas the highest agronomic efficiency (AE) and nutrient recovery efficiency (NRE) was observed with the foliar spray of zinc sulphate $(0.1 \% \mathrm{Zn}$ solution) with lime and the physiological efficiency (PE) was recorded highest with application of $7.5 \mathrm{~kg} \mathrm{Zn/ha}$ through $\mathrm{ZnSO}_{4}(21 \% \mathrm{Zn})$ to the soil. Thus it can be concluded that application of $7.5 \mathrm{~kg}$ $\mathrm{Zn} /$ ha through $\mathrm{ZnSO}_{4}(21 \% \quad \mathrm{Zn})$ as soil application is the best option for achieving higher yield of basmati rice.

\section{References}

Adhikari, T., Rattan, R.K. 2007. Distribution of $\mathrm{Zn}$ fractions in some major soils of India and impact on nutrition of rice. Commun Soil Sci Plant Anal 38: 2779-2798

Anonymous 2018. Agriculture statistics at a glance, Department of Agriculture and Co-operation, Ministry of Agriculture, Government of India, New Delhi.

Beebout, S.J., Tuyogon, D., Rubianes. F., Castillo, O., Larazo, W., Bunquin, M. and Laureles, E. 2010. Improved zinc management strategies for rice scientists and farmers. In: Proceedings of 2010 International Annual Meetings of ASA-CSSA-SSSA, October 31 to November 04, 2010, Long Beach, California, USA

Cakmak, I. 2008. Enrichment of cereal grains with zinc: Agronomic or genetic biofortification. Journal of Plant and Soil 302: 1-17.

Cheema, N.M., Ullah, N. and Khan, N.U. 2006. Effect of zinc on the panicle structure and yield of course rice, IR6. Pakistan Journal of Agricultural
Research. 19(4): 33-37

Gao, X., Hoffland, E., Stomph, T.J., Grant, C.A., Zou, C. and Zhang, F. 2012. Improving zinc bioavailability in transition from flooded to aerobic ricea review. Agron Sustain Dev 32:465478

Ghatak, R., Jana, P.K., Sounda, G., Ghosh, R.K. and Bandopadhyay, P. 2005. Responses of transplanted rice to $\mathrm{Zn}$ fertilization at farmers' field on red and laterite soils of West Bengal. Journal of Inter Academicia 9(2): 231234

Ghoneim, A.M. 2016. Effect of Different Methods of $\mathrm{Zn}$ Application on Rice Growth, Yield and Nutrients Dynamics in Plant and Soil. Journal of Agriculture and Ecology Research International 6(2): 1-9

Khattak, S.G., Dominy, P.J., and Ahmad, W. 2015. Effect of $\mathrm{Zn}$ as soil addition and foliar application on yield and protein content of wheat in alkaline soil. $J$. Natn. Sci. Foundation Sri Lanka 43(4): $303-312$

Kumar, D., Kumar, R., Singh, P. and Kumar, P. 2017. Effect of different zinc management practices on growth, yield, protein content, nutrient uptake and economics on rice under partially reclaimed saltaffected soil. Journal of Pharmacognosy and Phytochemistry 6(5): 638-640

Mortvedt, J.J. and Gilkes, R.J. 1993. Zinc fertilizers. In: Robson AD (ed) Zinc in soils and plants. Kluwer, Dordrecht, The Netherlands, pp 33-44

Rengel, Z., Batten, G.D. and Crowley, G.E. 1999. Agronomic approaches for improving the micronutrient density in edible portions of field crops. Field Crops Research 60: 27-40

Romheld, V. and Marschner, H. 1991. Function of micronutrients in plants. In: Micronutrient deficiencies in 
global crop production. Springer, Berlin 93- 125.

Shivay, Y.S., Prasad, R. and Rahal, A. 2010. Genotypic variation for productivity, zinc utilization efficiencies, and kernel quality in aromatic rice under low available zinc conditions. Journal of Plant Nutrition 33: 1835-1848

Singh, A.K. Singh, N.P., Nongkyarih, P. 2014. Response of rice to $\mathrm{Zn}$ in the soils of Meghalaya. Fertilizer News 47(8): 53-54

Singh, M.V. 2007. Micronutrient deficiencies in crops and soils in India. In:
Micronutrient deficiencies in global crop production. Springer Berlin 93125

Slaton, N.A., Norman, R.J. and Wilson, C.E. 2005. Effect of zinc source and application time on zinc uptake and grain yield of flooded-irrigated rice. Agronomy Journal 97: 272-278

Welch, R.M. and Graham, R.D. 1999. A new paradigm for world agriculture: Meeting human needs, productive, sustainable and nutritious. Field Crops Research 60: 1-10

\section{How to cite this article:}

Rahul Kumar, Mukesh Kumar, Shipra Yadav and Rajendra Kumar. 2020. Effect of Sources and Methods of Zinc Application on Productivity, Nutrient Uptake and Zinc Use Efficiency of Basmati rice (Oryza sativa L.). Int.J.Curr.Microbiol.App.Sci. 9(01): 2231-2242.

doi: https://doi.org/10.20546/ijcmas.2020.901.252 